\title{
Effects Of Cryofrequency on Localized Adiposity in Flanks
}

Rodrigo Marcel Valentim da Silva', Manoelly Wesleyana Tavares da Silva², Sâmela Fernandes de Medeiros², Sywdixianny Silva de Brito Guerra ${ }^{3}$, Regina da Silva Nobre ${ }^{3}$, Patricia Froes Meyer ${ }^{4}$

\begin{abstract}
Background: Cryofrequency is a characteristic used in clinical practice to reduce localized and flaccid adiposity, and promotes heat in our tissues by maintaining a surface. Objective: To investigate the effects of Cryofrequency in the reduction of adiposity located on the flank region. Methods: This is an experimental study, consisting of 30 female volunteers between 20 and 40 years old with flank fat. The applications were performed once a week, totaling eight applications, using the Andrus Criofrequência ${ }^{\circledR}-$ ADOXY MEDICAL, with parameters of $350 \mathrm{w}$ of power, monopolar mode on the region of right and left flanks, with an area of $10 \mathrm{~cm}$ in height and $20 \mathrm{~cm}$ in width, for 8 minutes per area. The evaluations were performed before and after 4 and 8 Cryofrequency applications. Results: There was a reduction of the adiposity located in the flank region, with a significant decrease in the values of perimetry, plicometry and ultrasonography, and positive results in the questionnaire evaluating satisfaction and criofrequence reactions. Conclusion: Cryofrequency was effective for the treatment of localized adiposity, generating a positive satisfaction among the evaluated volunteers.
\end{abstract}

Keywords: Radiofrequency; Cryotherapy; Adipose Tissue.

\section{INTRODUCTION}

Among the main concerns with body aesthetics, localized fat remains the most discomfort. In pursuit of the standard demanded by society, subjects, especially women, undergo a series of treatments, from diets and alternative therapies to surgical interventions, to shape the body ${ }^{(1)}$. The search for safe and effective devices to shape the body in a non-invasive manner has increased over the last few years. Many modalities have been developed to target adipocytes, including ultrasound, cooling devices, light (laser), and radiofrequency ${ }^{(2)}$. Radiofrequency is indicated in all the degenerative processes that implies in the decrease or retardation of the metabolism, irrigation and nutrition, being generally used in chronic pathologies. It is also indicated in treatments of localized adiposity by providing the possibility of reducing the amount of the adipocytes, provoking homeostatic lipolysis and elastic fiber production, through vasodilation and irrigation below the treated zone, in addition to oxygenation and nutrition of the tissues ${ }^{(3)}$. The difference between radiofrequency and cryofrequency is that the last one has two technologies, multipolar and monopolar, that act simultaneously, and function with cold-inducing term of up to -10 degrees, causing a thermal shock in the tissue ${ }^{(2,4)}$. The energy released in monopolar cryofrequency leads to better circulatory and nutrient supply, acceleration of catabolites elimination, lipolysis, connective tissue contraction, increased oxygenation and tissue hydration. While the bipolar applicator generates an electrical circuit with a more superficial effect ${ }^{(2,4)}$.

The localized fat is a hypertrophy of unilocular adipose cells, found mainly in the flanks region, determining several bulges due to the existing volume. This hypertrophy is resistant to diets, massage and gymnastics because of the existing volume ${ }^{(5)}$. In view of these characteristics and the search for effective treatments for this condition, it is justified to carry out this research, aiming to investigate the effects of Cryofrequency in the reduction of adiposity located in the flank region.

\section{METHODS}

\section{Sample and research characterization}

This is a quasi-experimental study. The volunteers with abdominal adiposity were selected by convenience, in the city of Natal-RN, after the study was approved by the Ethics Committee of the Universidade Potiguar, with protocol number

Corresponding Author: Rodrigo Marcel Valentim da Silva. Address: Rua Nossa Senhora de Fátima, 312b, Alecrim. CEP: 59030080. Natal (RN), Brazil.

Telephone: +55 84 991645644. E-mail: marcelvalentim@hotmail.com

1 Universidade Federal do Rio Grande do Norte (UFRN), Natal, RN, Brazil.

Full list of author information is available at the end of the article.

Financial support: The authors declare that there was no financial support.

Submission date 18 December 2017; Acceptance date 03 July 2018; Publication date 23 December 2018 
1.962.948. The sample was composed by 50 female volunteers with age range from 20 to 40 years old, presenting adiposity located on flanks, comprehension capacity, preserved local sensibility, and without circulatory alterations. The excluded volunteers were the ones who were not available for research, on a diet, regularly exercised and did not signed the Informed Consent Form.

\section{Procedures}

Initially the volunteers were submitted to an initial evaluation, through the Protocol of physiotherapy evaluation in located adiposity (PAFAL) ${ }^{(6)}$ composed by: identification, anamnesis, physical examination, measurements and tests (weight, height, BMI, skinfolds, and circumference measures). The perimetry was performed using a Tape Measure Fiber ${ }^{\circledR}$ to obtain the measuring circumference $5 \mathrm{~cm}$ below, above and at the umbilical scar line. The plicometry was carried out with a plicometer of the brand Sanny ${ }^{\circledR}$ which has measurement from 0 to $65 \mathrm{~mm}$, in which the skinfold of flanks was measured three times $2 \mathrm{~cm}$ above the supra-iliac region, with a result based on the mean values obtained in the three measurements. Subsequently, they were submitted to the ultrasound device EcopalmWifi (10MHZ), manufactured by Guangzhou Medsinglong Medical Equipment performed by a medical specialist for analysis and measurement of adipose tissue. The examination was performed in the right and left flank region, in an area of $10 \mathrm{~cm}$ in height and $20 \mathrm{~cm}$ in width. The transducer was left in the pendent form, perpendicular to the cutaneous tissue, without pressure on the skin so that there was no influence on the result represented in Figure 01.

The photogrammetry was held using a NIKON ${ }^{\circledR}$ D5000 camera. The registry was performed in orthostatism, frontal and lateral view (right and left) and the volunteer with shoulders flexed at 90 - The camera was positioned on a tripod at a height of $90 \mathrm{~cm}$ from the ground and placed at a distance of $60 \mathrm{~cm}$ from the volunteer. The photographic record was done in three stages: Evaluation 1, Evaluation 2 (after 4 sessions of application of Cryofrequency), and Final Evaluation (after 8 sessions of application of Cryofrequency). The application of the cryofrequency was done using the Andrus Criofrequency ${ }^{\circledR}$ - of the brand ADOXY MEDICAL and performed in right and left lateral decubitus with the applicator positioned in the same place where the ultrasonography was performed. The parameters were: $350 \mathrm{w}$ of power, monopolar mode in the right and left flank region, in an area of 10 centimeters high and 20 centimeters wide, during 08 minutes per area (protocol suggested by the company, there are no records of data in the literature). Treatment consisted of an initial evaluation, 1 weekly session for 8 weeks (8 sessions), a re-evaluation after 4 applications, and a final evaluation. At each session the patients were submitted to plicometry, perimetry and weighing. Participants answered a satisfaction questionnaire adapted from Segot-chicq et al., 2007. Based on it, a questionnaire for comparative evaluation of skin appearance was constructed before and after the use of cryofrequency.

The data obtained for each evaluation were recorded in an Excel spreadsheet and then submitted to a statistical arrangement. The analysis of the statistical data was performed through Service Statistical Package for the Social Science - SPSS (version 22.0) program $^{\circledR}$. The descriptive statistics were presented in the form of tables and graphs. The verification of normality of the data was through the Kolmogorov-Smirnov test. The paired t-test was used to compare the values between the initial and final evaluations. The level of significance of the results obtained is $95 \%$ with $\mathrm{p}<0,05$.

\section{RESULTS}

Initially 50 women were included in this study, there were 20 dropouts, and the final sample was 30 volunteers. Volunteers had mean height of $1.60 \pm 0.06 \mathrm{~cm}$, and mean age of 21.6 years. When analyzing Table 1, which presents the collected data of weight and BMI throughout the research, it is noticed that there was no significant change.

After the application of Criofrequency there was a significant reduction of the plicometry measurements, with a mean difference of $2.44 \mathrm{~mm}$ in relation to the first evaluation, and the perimetry measurements, with a difference of $5.5 \mathrm{~cm}$. A reduction of the fat layer of $0.19 \mathrm{~cm}$ was observed on the ultrasound. All measurements showed a significant reduction with $\mathrm{p}$ value $<0.05$. (Table 2 ).
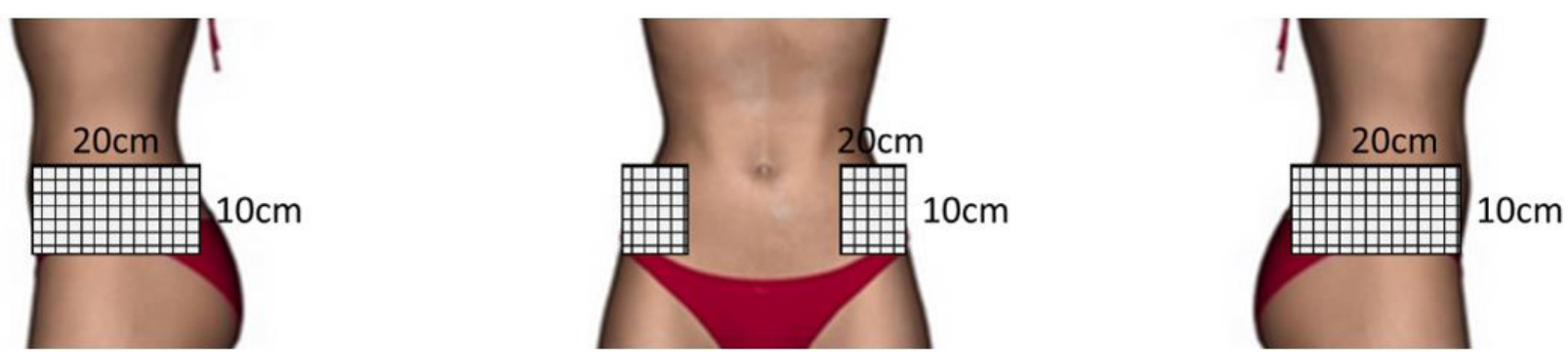

Figure 1: Schematic drawing of ultrasonography of cutaneous tissue analysis. 
Table 1: Weight and Bdoy Mass Index data.

\begin{tabular}{cccc}
\hline & Initial & Final & P-value \\
\hline Weight & $68.75 \pm 8.9$ & $68.03 \pm 9.11$ & 0.98 \\
BMI & $24.58 \pm 3.43$ & $26.44 \pm 3.04$ & 0.96 \\
\hline
\end{tabular}

Note: BMl=Body Mass Index

Table 2: Data of plicometry, perimetry and ultrasound of the volunteers submitted to the criofrequency.

\begin{tabular}{lccc}
\hline & Initial & Final & P-value \\
\hline Plicometry & $30.34 \pm 7.1$ & $27.9 \pm 8.1$ & 0.001 \\
Perimetry & $89.37 \pm 7.1$ & $83.87 \pm 6.2$ & 0.001 \\
Ultrasound & $1.48 \pm 0.3$ & $1.29 \pm 0.5$ & 0.001 \\
\hline
\end{tabular}
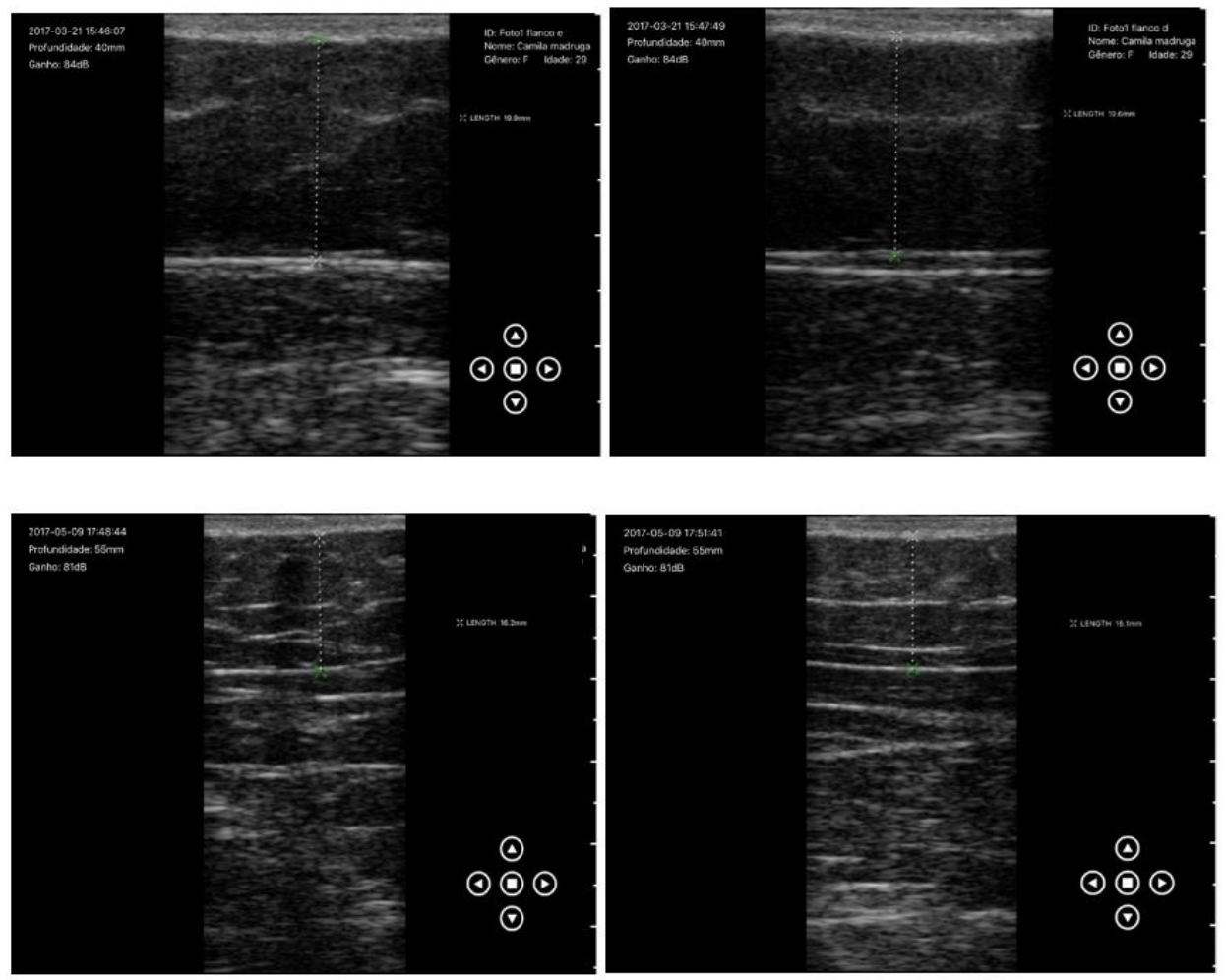

Figures 2A, 2B, 2C and 2D: Ultrasonography of right and left flanks demonstrating the reduction of adipose tissue, being respectively, figure $2 \mathrm{~A}$ the right flank, figure $2 B$ the left flank of the initial evaluation, figure $2 C$ the right flank and figure $2 D$ the left flank of the final evaluation. The patient's personal identification data was covered for identity protection.

The images of the ultrasound present reports made by the responsible doctor that emphasize the measures of the adipose layer in the flanks region, according to the figure 2 .

In the description of reactions after the cryofrequency application it was observed that $80 \%$ of the sample showed hyperemia during the treatment, with $8 \%$ only in the first session, $38 \%$ in the first two sessions, $8 \%$ in the first four sessions and $46 \%$ in all the sessions. Of the volunteers who presented hyperemia, $53 \%$ stated that they disappeared shortly after the application, $37 \%$ stated that it lasted 1 hour approximately, $7 \%$ that lasted 2 to 3 hours approximately, and $3 \%$ stated that it lasted more than three hours. As for the sensation of discomfort caused by the cold shock of the cryofrequency, $83 \%$ reported that they felt discomfort, and $17 \%$ reported having no sense. Of the volunteers who felt discomfort, $16 \%$ noticed in the first session, $32 \%$ noticed in the first two sessions, $36 \%$ noticed in the first four sessions, and $16 \%$ felt discomfort (little shocks during the application) in all sessions.

Regarding the perception of the looser clothes, $90 \%$ said they perceived, and $10 \%$ said they did not perceive. Of those who noticed the looser clothes, $31 \%$ noticed from the second 
week, $54 \%$ noticed from the fourth week, $11 \%$ noticed from the sixth week and $4 \%$ noticed in the eighth week. It was questioned if there was a difference in skin texture comparing two months before the application, and $10 \%$ considered the skin much more firmly, 50\% considered the skin more firmly, $7 \%$ considered the skin with little firmness, and 33\% stated that they did not see any difference. Of the volunteers who noticed greater firmness in the skin, $27 \%$ observed from the second week and $73 \%$ observed from the fourth week. As for the perception of smaller and more shaped flanks, $90 \%$ realized and $10 \%$ did not perceive. Of the volunteers who noticed, $30 \%$ observed from the second week, 55\% observed from the fourth week, $11 \%$ observed from the sixth week, and $4 \%$ observed from the eighth week.

The analysis of the satisfaction degree of the volunteers after the application was performed, so that the data obtained through the adapted satisfaction questionnaire were analyzed. It was observed that $97 \%$ of the sample were satisfied with the treatment and $3 \%$ of the volunteers were not satisfied. As for the evaluation of the volunteers regarding the attribution of a concept to the results of this treatment, $37 \%$ said that it was an excellent treatment, 33\% said to be very good treatment and $30 \%$ said to be a good treatment. The alternatives regarding being a weak treatment and that would not indicate to anyone was not signaled.

\section{DISCUSSION}

The 8-week intervention was not enough to change weight and BMI, with the $p>0.05$. This result corroborates with Silva (2016), who evaluated the criofrequency as a therapy for reduction of abdominal adiposity in women. It is believed that changes in dietary habits and regular practice of exercises are necessary to reduce these variables, since criofrequency would act locally ${ }^{(7)}$. There was a significant decrease in perimetry and plicometry measurements. Perhaps this fact can be justified by a greater lipolysis action of the cryofrequency in relation to other devices, since the Cold stress can recruit specific proteins (HSPs) and these can lead to apoptosis of adipose tissue cells, as reported by Inacio (2016) in a literature review ${ }^{(2,8)}$.

Some studies showed that the inflammatory response (consequence of thermal changes) causes the release of HSP60 in adipocytes, achieving the release of pro-inflammatory substances and insulin resistance. These studies also showed that the shock proteins are involved in the activation of the innate cells of the immune system, which results in the infiltration of macrophages into the adipose tissue by the release of Chemokines, such as MCP-1, which regulates the migration of phagocytic cells ${ }^{(2,8)}$. In monopolar form, the electromagnetic waves allow the penetration of the heat depth in the tissue, while the cooling is done in the surface for protection of the cutaneous tissue. Depending on the intensity of cold exposure, cell stress induces apoptosis (programmed cell death $)^{(2)}$, justifying the decrease of the fat layer that was found in the results through the ultrasonography evaluation.

Regarding the satisfaction with the result of the treatment, the volunteers indicated a higher percentage that the result was positive, as well as the most cited concepts evaluated by them are "excellent", "very good treatment" and "good treatment". This demonstrates a good receptivity of the technique despite the discomfort reported by them. There is a need for a better understanding of the mechanisms of action of cryofrequency. One possible explanation would be the ability to achieve higher temperatures and achieve not only a comfortable skin flaccidity effect but also effects on adipose tissue through higher and superficial temperatures more comfortable to the patient ${ }^{(9,10)}$.

\section{CONCLUSION}

It was concluded that the cryofrequency showed positive results for the reduction of the localized adiposity, causing a decrease of the fat layer measured through the perimetry, plicometry and ultrasonography, and generating a positive satisfaction with the treatment. It is suggested further studies to clarify and explain their mechanisms of action, varying parameters and equipment models, i.e., varying the physical energy used.

\section{AUTHORS' CONTRIBUTIONS}

RMVS: study design; MWTS and SFM: data collection; SSBG and RSN: statistical analysis; PFM and RMVS: critical review of the article. All authors read and approved the final manuscript.

\section{CONFLICT OF INTEREST}

The authors declare that there was no conflict of interest.

\section{AUTHORS DETAILS}

2 Universidade Potiguar (UNP), Natal, RN, Brazil.

${ }^{3}$ Centro Universitário do Rio Grande do Norte - UNI-RN, Natal, RN, Brazil.

${ }^{4}$ Universidade Federal do Rio Grande do Norte - UFRN, Natal, RN, Brazil.

\section{REFERENCES}

1. Meyer PF, Carvalho MGF de, Andrade LL de, Lopes RNS, Delgado AM, Araújo HG de, et al. Efeitos da ultracavitação no tecido adiposo de coelhos. Fisioter Bras. 2012;13(2):106-11.

2. Inacio RF. Análise comportamental do tecido adiposo frente ao tratamento de radiofrequência e criofrequência: revisão bibliográfica. Revista Saúde em Foco. 2017;9(1):248-56.

3. Carvalho GF, Mesquita Filho JJT, Meyer PF, Ronzio OA, Medeiros JO, Nóbrega MM, et al. Avaliação dos efeitos da radiofrequência no tecido conjuntivo. Dermatologia \& Cosmiatria. Rev Bras Med. 2011;68:10-25.

4. Chin JH, Okazaki M, Hu ZW, Miller JW, Hoffman BB. Activation of heat shock protein (hsp)70 and proto-oncogene expression by alpha1 adrenergic agonist in rat aorta with age. J Clin Invest. 1996;97(10):2316-23.

5. Macedo ACB de, Cunico F, Sassi L, Albuquerque J, Borges F. Efeitos da aplicação da corrente polarizada e da iontoforese na gordura localizada em mulheres. Fisioter em Mov. 2013 Sep;26(3):657-64. 
6. Mendonça AG, Rodrigues RD, Coradi DP, Cruz LB, Meyer PF, Antunes M de $\mathrm{J}$, et al. Protocolo de avaliação fisioterapêutica em adiposidade localizada. Fisioter Bras. 2008; Especial:26-31.

7. SILVA, Márcia Corrêa. Avaliação do uso da criofrequência como terapêutica para a redução da adiposidade abdominal. 2016. 23 f. Monografia (Graduação) - Faculdade de Ciências da Educação e Saúde, Centro Universitário de Brasília, Brasília, 2016.
8. Carvalho MGF de, Silva RMV da, Mesquita Filho J, Meyer PF, Ronzio OA, Medeiros J de O, et al. Avaliação dos efeitos da radiofrequência no tecido conjuntivo. Rev Bras Med. 2001;68:10-25.

9. Meyer PF. Criofrequência In: I Estética in Nordeste. 1st ed. NE El, editor. Fortaleza; Data: 28 a 30 de outubro de 2017. Acesso: 12/2017: http:// www.esteticainnordeste.com.br/congresso_oficial.php

10. Manual Andrus Criofrequência. Fabricante do Aparelho de Criofrequência. Adoxy Medical. Acesso: 08/2017. 